\title{
Gifted students' perceptions of their acceptance of evolution, changes in acceptance, and factors involved therein
}

\author{
Jason R Wiles ${ }^{1,2,3,4}$
}

\begin{abstract}
Background: Few reports have tracked changes in the levels of acceptance of evolution among high school students, and there have apparently been no studies exploring the levels of acceptance of evolution among gifted high school students in transition to post-secondary education. And, although many have measured acceptance of evolution via various instruments, there has been little information regarding what students consider to be important factors affecting changes in their positions of acceptance or rejection of evolution. These were explored using open-ended questionnaires and interviews with students in a population previously documented to have shown significant changes in acceptance of evolution.

Results: Qualitative data reveal a complex and individualized landscape of factors students perceive to influence their acceptance of evolution. The majority of participants who accepted evolution ranked factors related to evidence most highly among those leading to their acceptance. Participants who had become more accepting of evolution often cited evidence, but were more likely to list having become "more open-minded" as the primary influencing factor. Participants who rejected evolution were more likely to list "the Bible" or "religious beliefs" as the chief factor affecting their position regarding evolution, and the second most frequently and highly ranked factor cited by evolution rejecters was that they had been "taught" or "raised" not to believe in evolution. When discussing evidence, they were more likely to refer to their perceptions of its insufficiencies.

Conclusions: Patterns and trends common among groups of participants emerged from the qualitative data. It appears that students who accept evolution appeal more strongly to evidence than those who are unsure about or reject evolution; that students often appeal to their religion as a factor influencing their level of acceptance of evolution whether they accept evolution, reject evolution, or are in transition; and that students may have difficulty with the evolution of human beings even if they accept all other aspects of evolution. Other trends suggest that students who become more accepting of evolution may go through "stages" of changed acceptance involving acceptance of increasingly ancient ages for Earth and universe and expanding limits within which they accept that evolution can occur.
\end{abstract}

Keywords: Evolution; Acceptance of evolution; Qualitative; Secondary education; Post-secondary education; Student perceptions; Purposive sampling; Arkansas

\footnotetext{
Correspondence: jrwiles@syr.edu

'Department of Biology, Syracuse University, 107 College Place, Syracuse,

NY 13244, USA

2Department of Science Teaching, Syracuse University, 101 Heroy Lab,

Syracuse, NY 13244, USA

Full list of author information is available at the end of the article
}

\section{实 Springer}

(c) 2014 Wiles; licensee Springer. This is an Open Access article distributed under the terms of the Creative Commons Attribution License (http://creativecommons.org/licenses/by/2.0), which permits unrestricted use, distribution, and reproduction in any medium, provided the original work is properly cited. 


\section{Background}

Given the overwhelming acceptance of evolution by the scientists most qualified to assess its validity, and the centrality of evolution to the broad understanding of biology and allied sciences under a unified framework, and the intense support from the science education community of evolution as a foundational principle around which to build knowledge of the natural world, the problem of widespread student rejection of evolution is of immense importance (Wiles 2010). In fact, Stephen Jay Gould described evolution education as, "one of the most important issues of our age" (Gould 2001, p. 3).

Some readers may question whether student acceptance of evolution is, or should be, a goal of science education, and, consequently, whether rampant public rejection of evolution does in fact constitute a failure of science education. There has been some debate around this question among various educators and researchers (Alters 1997; Kearney 1999; Smith and Siegel 2004; Nehm and Schonfeld 2007). But the positions of scientists, science educators and their societies are consistently and staunchly adamant that biology and a variety of other branches of science cannot be properly understood outside of the context of evolution (Wiles 2010; Sager 2008; Dobzhansky 1973), and increased understanding of evolution is surely a goal of biology education (American Association for the Advancement of Science AAAS 2011; NGSS Consortium of Lead States 2013). Ingram and Nelson (2006) underscore this point, asserting that student understanding of evolution is more important than student acceptance of evolution. Although this may be true, there appears to be somewhat of a catch22 , at least when dealing with some students, for a number of researchers have argued that lack of acceptance of a concept may, in fact, prevent students from developing an understanding of the concept (Cobern 1994; Meadows et al. 2000; Scharmann 1990; Smith 1994). Such discussions often include distinguishing acceptance from belief.

\section{Acceptance vs. belief}

Alters (1997) argued that the terms "accept" and "believe" are, for practical purposes, essentially equivalent - both being words used to express the degree of confidence held by an individual with regard to some idea. In support of this view, Alters quoted various instances in which scientists have used the word "believe" and its cognates in the same way in which others may use various forms of the word "accept," and he bolstered his argument with the assertion that students would not likely distinguish between these two terms (Alters 1997).

Other science educators and researchers maintain different meanings for these two words (Ingram and Nelson 2006; National Academy of Sciences 1998; National Academy of Sciences 2008; Smith 1994; Smith and Scharmann 1999; Southerland and Sinatra 2003;
Southerland et al. 2001; Sinatra et al. 2003). Among those who distinguish belief from acceptance, beliefs are described as subjective and are regarded as being based on personal conviction. Acceptance, on the other hand, is defined as being based on a "systematic evaluation of the evidence" (Sinatra et al. 2003, p. 512). Nehm and Schonfeld (2007) maintain this distinction; however, like Alters, they caution that:

such solid distinctions dissolve in many research and classroom contexts because research participants may be (a) unaware of the differences in the meanings of these terms and (b) unlikely to recognize that their beliefs are irrational or not based on evidence, thus rendering the distinctions between belief and acceptance meaningless in self-reports. (p. 719)

Nehm and Schonfeld (2007) further assert that it is likely that scientists "believe, rather than accept, much of their scientific knowledge" (p. 719), especially knowledge outside of their particular discipline. However, I would argue that scientists, by virtue of being acquainted with the rigor and scrutiny under which scientific knowledge is generated, may still accept such knowledge from outside of their own specialty, recognizing the vetted work of other scientists as credible evidence.

Student understanding of the nature of science may be effectively addressed through teaching students about the belief/acceptance demarcation (Southerland et al. 2001). Smith (1994) posits that the distinction between belief (when meaning subjective and based on personal conviction) and acceptance (when meaning a systematic evaluation of the evidence) is a crucial aspect of understanding the nature of scientific knowledge. Ha et al. (2012) agree with such careful and deliberate use of language in science classrooms, but they posited that it is more important to help students understand the "multiple meanings and applications" (p. 99) of words, especially in the context of science. In a very well-reasoned discussion, Ha et al. (2012) introduced a new concept in this discussion, the Feeling of Certainty (FOC), which they characterize as representing a cluster of related mental states that "emerges involuntarily without prior, conscious cognition...in association with conscious thoughts" (p. 98).

Sinatra et al. (2003) warned that the use of "belief" in the context of science education research, especially around the topic of evolution, "has the potential for blurring the distinctions between scientific knowledge and religious belief" (p. 512). An earlier development of this theme (Southerland et al. 2001) included similar reasons for demarcation between belief and acceptance but added a further argument based on ethical concerns. The authors concluded that teaching with the objective of student "belief" in evolution may suggest to students 
that they should abandon their previous religious convictions, and it might further imply that they should do so without sufficient examination of the evidence. Hence, teaching toward student "acceptance of evolution as the best scientific explanation currently available" (p. 341) is a more ethically defensible educational goal as long as it is not required of students (Southerland et al. 2001), a conclusion similarly reached by Smith and Siegel (2004).

For these reasons, and for the sake of clarity, I will, for the purposes of this research, maintain a distinction between belief and acceptance. For the purposes of this research, I will avoid using "belief" with regard to evolution, and will assume, as in Sinatra et al. (2003), that acceptance "refer[s] to a learner's personal assessment of the validity of a construct" (p. 512). Under the conditions outlined by Southerland et al. (2001), I will assume "acceptance" of evolution as "the best scientific explanation currently available" (p. 341) to be an appropriate goal of science education.

\section{Teaching toward acceptance}

Reflecting on his experiences with people who had initially resisted evolutionary ideas but had eventually overcome their original rejection of evolution, Pigliucci (2002) called for the research community to focus on individuals who had progressed from rejection of evolution to acceptance. After five years of little response, he renewed his appeal, writing, "It is important to find out how they did it, because that insight provides us with crucial clues as to what works and what does not" (Pigliucci 2007, p. 296).

There has been a great deal of scholarship around the teaching and learning of evolution (Smith 2010a, b; Sickel and Friedrichsen 2013); however, the literature pertaining to evolution education is fraught with ambiguities regarding the effectiveness of courses containing evolutionary content toward increasing student acceptance of evolution. For example, Wilson (2005) and Ingram and Nelson (2006) reported increased acceptance of evolution among university students as a result of instruction. On the other hand, neither Bishop and Anderson (1990) nor Lawson and Worsnop (1992) found evidence of change in student acceptance of evolution after instruction.

Although some researchers had reported changes, and others no change, in students' levels of acceptance of evolution as a result of instruction, until Wiles and Alters (2011), from which this study continues, there had apparently been no reports of the effectiveness of a course or experience (described in the Methods section below and in Wiles and Alters (2011)) which specifically addressed such an extensive inventory of factors which may influence student acceptance of evolution.
Additionally, much of the relevant research has been conducted in college or university settings. Indeed, Lloyd-Strovas and Bernal (2012) reviewed 26 articles on evolution instruction at the university level over a span of 30 years, and while concluding that this field of study has been rather disjointed and marked by results that are difficult to compare, the authors noted five trends among the reviewed studies. Namely, there appears to be a positive relationship between understanding the nature of science and acceptance of evolution, and there is also a positive relationship between instruction and both understanding and acceptance of evolution. However, confoundingly, there appears to be no relationship between understanding and acceptance of evolution, and the relationship between acceptance of evolution and religious belief is unclear (Lloyd-Strovas and Bernal 2012). This may be in part because, as Opfer et al. (2012) found, college-level biology students tend to understand evolution both in terms of "scientific concepts" and "naïve cognitive biases" (p. 769).

Although Moore and colleagues have investigated how college students have been influenced by their high school experiences in Minnesota (Moore, 2007a; Moore, 2007b; Moore, Froehle, Kiernan, \& Greenwald, 2006), there are comparatively few reports tracking changes in the levels of acceptance of evolution among high school students or exploring the levels of acceptance of evolution among high school students in transition to postsecondary education.

Finally, in the 15 years since Dagher and BouJaoude (1997) examined how Lebanese biology majors accommodated evolutionary science with their existing religious beliefs, few researchers have extensively explored students' own articulations regarding what factors they personally consider to be important in determining their positions of acceptance or rejection of evolution. This is a difficult task, and not without substantial conceptual and methodological obstacles, as Ha et al. (2012) have shown that students have difficulty with tracings of their thinking and reasoning processes and may not be metacognitively aware of the origins of their thoughts and beliefs. With this cautionary note in mind, however, it is nonetheless important to ask students with varying positions on evolution, especially those who may have recently changed or may be in the process of changing their minds regarding evolution, which factors they perceive to influence their thinking. Hence, the research questions that guided this study were as follows.

Primary research question:

How do students perceive their acceptance or rejection of the occurrence of biological evolution changing in their final high school and early university years? 
Secondary questions:

A) What factors do students perceive as influencing their acceptance or rejection of the occurrence of biological evolution?

B) How do students perceive these factors to rank in order of influence on their acceptance or rejection of the occurrence of biological evolution?

C) What patterns arise among students' articulation of why their level of acceptance or rejection of the occurrence of biological evolution has changed?

\section{Methods \\ Sample \\ Participants and location of research}

Data were primarily collected in a secondary level public education setting in Arkansas, a state located in the American mid-south along what is commonly referred to as the "Bible Belt". The topic of evolution is of particular interest in Arkansas, in part due to formal attempts to undermine the teaching of evolution in the state's public schools. These efforts go back as far as the Scopes era, and Arkansas has played an inglorious part in the national debate as state laws undermining evolution education have repeatedly been struck down in the federal courts (Epperson, et al. v. Arkansas 1968; McLean v. Arkansas Board of Education 1982). Even given the fates of these laws from decades past, more recent anti-evolution bills have been introduced in the Arkansas legislature (Arkansas House 2548 2001; Arkansas House 2607 2005). Local school districts have also played a role; for example, a warning label was for years affixed to biology textbooks in the state's Beebe Public School District, where they were finally removed after the American Civil Liberties Union of Arkansas warned the district of imminent legal perils (National Center for Science Education 2005). Moreover, even in the absence of such formal pressure, there is a generalized climate of hostility to teaching evolution in Arkansas that results in the frequent downplaying or omission of evolution in its public school science classrooms (Wiles 2006a, 2008), and the state's official education standards regarding evolution have earned failing marks time and again (Gross et al. 2005; Lerner 2000). Hence, it is unsurprising that many of the participants reported the course in evolution (as described in Wiles and Alters 2011) was their first exposure to a coherent discussion of evolution and the evidence for it.

Participants in this research project were from the same population as presented in Wiles and Alters (2011), that is, they were students of the Arkansas Governor's School (AGS) who had taken a course on evolutionary science during the program. AGS is a high-school-level summer program of the Arkansas Department of Education, and students of AGS are selected to attend the six-week program from a pool of applicants from across the state, whether they attend public schools, private schools or home schools. All AGS students have completed their junior year of high school (Grade 11) and are considered to be 'rising' seniors (entering Grade 12). Thus, they are generally between the ages of 16 and 17 when they attend the program. This population is of particular interest, as Wiles and Alters (2011) measured substantial increases in acceptance of evolution among these students.

All participants in this research project were enrolled in a course designed to address scientific and related factors identified in the literature as potentially affecting student acceptance of evolution. The course was multidisciplinary in nature and included instruction on the nature of science; the history of evolutionary theory; a survey of methods used in determining the chronology of cosmological, geological and biological history; evidence of evolution drawn from the Earth and space sciences and from the biological sciences; evolutionary mechanisms; current theories regarding the pre-biotic Earth and the origin of the first organisms; and practical applications of evolutionary science, such as those in the fields of medicine and agriculture. Efforts were made to encourage critical thinking, and students were challenged directly to compare preconceptions associated with creationism (though without explicitly referring to such alternative conceptions as creationist or religiously based ideas) with explanations that are more consistent with scientific evidence, as suggested by Alters and Nelson (2002) and by Nelson (2007). Also, in keeping with Pigliucci's (2002) assertion that acceptance of evolution may increase with the number of sources and formats of information about evolution and its evidence, a variety of delivery methods were employed and guest experts were invited throughout the course.

AGS is an ideal setting for incorporating the range of factors potentially affecting student acceptance of evolution. Outside of the course on evolutionary science, the AGS educational experience (its core courses, additional lectures and workshops, and exposure to students and faculty from diverse backgrounds) supports instruction and experiences related to several of the non-scientific factors which are not always included, and some of which may not be appropriate, in school science classrooms. Factors addressed in the AGS experience outside of the course on evolution included: the false dichotomy between science and religion, the perceived problem of evolution and racism, additional attention to misconceptions rooted in physics, critical thinking, epistemological disposition, progression beyond cognitive dualism, and development of both personal and social awareness involving encouraging students to value individuals who are different from themselves and ideas differing from their own. A more extensive explanation of AGS and the educational experience to which the participants were exposed can be found in Wiles and Alters (2011). 
Data were collected among the most recent AGS cohort through open-ended questionnaires (Appendix A) administered to students one year after their AGS experience $(n=37$ out of 81 solicited, a response rate of about $46 \%)$, and from interviews $(n=27)$. These were the same students reported on in Wiles and Alters (2011). Data were also obtained from archived materials from the evolutionary science course and a total of three years of prior iterations of the course. The archived materials included informal, anonymous, pre-course surveys administered by the course instructor $(n=323)$ and formal, anonymous student evaluations of the course administered by AGS staff $(n=318)$. Additional interview subjects $(n=9)$ were AGS alumni who had graduated from high school and were engaged in postsecondary education at various public or private colleges and universities ranging in size, geographic location and religious affiliation. Most AGS students have been identified as gifted, and those who take the course on evolution generally exhibit high aptitude and motivation in science. The student population to which the questionnaires were administered comprised a moderate majority of females (58\%) over males (42\%). A wide range of racial, ethnic, religious and socio-economic diversity was represented (See Wiles and Alters 2011 for a detailed description of demographic information).

As the participants were mostly minors, informed consent by the students' parents was required in almost all cases. Students who were minors were brought through the AGS registration process by their parents or legal guardians on the opening day of the program, and the AGS administration allowed a special station to be set up for natural science students during the registration process. At this station, parents or guardians were presented with formal letters explaining the nature of the research, and they were allowed to ask questions if they had concerns or wanted further information. Consent was freely given by the parents or guardians of all participants who were minors. Student participants were also informed about the nature of the research via a similar letter, and all subjects granted their voluntary assent. Students and alumni who were age 18 or over gave their own consent without the requirement of parental approval. All procedures were conducted in accord with the certification issued by the appropriate university ethics review board.

\section{Instrumentation}

\section{Students' perceptions of evolution acceptance, changes} therein and factors involved

A subset of participants who were actively enrolled in AGS at the time this research was conducted, as well as a subset of AGS alumni who had experienced the AGS curriculum and prior iterations of the evolutionary science course in previous years, were interviewed. These participants were asked to report on their own perceptions of their levels of acceptance of evolution, any perceived changes in their evolution acceptance, and the relative importance of factors they perceived as influencing their acceptance of evolution. Participants were also presented with open-ended questions about their perceptions of their acceptance of evolution, how their acceptance levels might have changed during the previous year, and what factors they thought had influenced their acceptance of evolution.

Additionally, although they were not formally designed as instruments for the purpose of research, archived materials from the evolutionary science course and from a total of three previous AGS sessions were also analyzed. These materials include pre-course surveys and post-course evaluations that revealed information about students' prior educational experiences regarding evolution, students' self-reported levels of prior knowledge about evolution, and their attitudes toward evolution and the AGS Natural Science course on evolution.

\section{Administration of interviews}

Participation in the interview process was entirely voluntary, and participants were assured anonymity. No identifying information was contained in the recordings of the interviews.

Students and former students were selected to participate in the interview process based on several criteria. For participants who were actively enrolled in AGS at the time of the research and who had indicated on the signed response to the informed consent letter that they were willing to participate in interviews, appointments for interviews were made according to their academic schedules and availability. As many participants as possible were interviewed, given the constraints of time and participant availability. For alumni, participants were purposively selected based on criteria aimed at collecting data from students with a variety of experiences. Three former students from each of the three prior AGS sessions were interviewed. Three participants were entering their first year of post-secondary study, three were entering their second year of college, and three were rising juniors at universities. Archived course materials were reviewed, and potential alumni participants were contacted based on responses to items that indicated possible changes in their assumed levels of acceptance of evolution. Other factors in the selection of alumni participants included the researcher's ability to contact potential participants and their proximity to the research site, which affected scheduling availability.

Interview participants were invited to choose the setting for their interview session in which they felt most comfortable. Selected settings included classrooms, 
restaurants and coffee shops, participants' homes, a bookstore, a designated campus prayer room and a small Christian chapel.

The semi-structured interviews were typically $45 \mathrm{mi}-$ nutes to one hour in length. The survey questions mainly focused on exploring participant acceptance of evolution and the factors they perceived as influencing their acceptance. Although specific questions related to participants' acceptance of evolution were asked in all cases, participants were encouraged to elaborate on their understandings of evolution, on how their religious beliefs may influence their thoughts about evolution and on their ideas, feelings and concerns about evolution. All interviews were audio-recorded and repeatedly reviewed during analyses.

\section{Data analyses}

Qualitative data (interviews; open-ended responses to the informal, pre-course survey; and the formal course evaluations) were analyzed through coding, constructing profiles, and thematic and cross-case analyses to examine patterns of similarities and differences (Maxwell 2005; Miles and Huberman 1994). Interviews were analyzed through line-by-line coding to identify recurrent concepts and those of importance to the participants (Strauss and Corbin 1998). Individual profiles were constructed by collecting codes into larger categories and themes. The constant comparative method was also used to examine the relationship between important concepts and themes related to the research questions during analysis of the interview data (Glaser and Strauss 1967).

\section{Methodological assumptions}

Because most AGS students have been identified as gifted, and because the participants exhibited high aptitude and motivation for study in the natural sciences, the sample is not representative of high school students in general. However, it is reasonable to assume that the sample is similar in most respects to students in typical advanced placement, honors or accelerated science courses at the secondary level and/or in transition to the post-secondary level.

The qualitative portions of this study are not presumed to be generalizable to any larger population. Participants' responses to interview questions are indicative only of their own experiences and understandings. However, it is reasonable to assume that the ideas and attitudes expressed by the participants in this study bear similarities to those of many students in typical secondary and early post-secondary classrooms, especially in advanced placement or honors courses. Finally, as self-reports, especially retrospective reports, can sometimes have low validity in many educational contexts (Ha et al. 2012), the necessary assumption that the participants accurately expressed their positions is a fundamental limitation of this and similar studies.

\section{Results and discussion}

In the following section, the findings of this investigation are presented in corresponding order to the research questions set forth above.

How do students perceive their acceptance or rejection of the occurrence of biological evolution changing in their final high school and early university years?

Open-ended responses from participants in the one-yearpost-course survey

Of the 37 participants who responded to the follow-up survey administered just over one year after their AGS experience, 36 individuals who had just graduated from high school answered the following question: "Do you think your level of acceptance or rejection of evolution has changed in the last year?" Of the participants responding, 69\% perceived no change in their level of acceptance or rejection of evolution during their senior year of high school, $28 \%$ thought that they had become more accepting of evolution, and 3\% reported that they were less accepting of evolution than they had been a year earlier.

\section{Interviews with AGS alumni in various stages of post-secondary education}

In this section, I present summaries of interviews with participants who had attended AGS one year, two years or three years prior to the interviews. Hence, these AGS alumni had just completed their final year of high school and were entering post-secondary education as freshmen $(\mathrm{n}=3)$, had completed one year of studies at university and were rising college sophomores $(\mathrm{n}=3)$, or had completed two years of college and were entering their junior year of post-secondary study $(n=3)$. Participants have been given pseudonyms to protect their anonymity.

\section{Perceived changes in acceptance of evolution among recent high school graduates entering post-secondary study: Becky, Tim and Rachel}

Becky accepts evolution "more firmly". Becky did not recall ever having doubted evolution, as applied to nonhuman species at least, although she had not been aware of its evidence and mechanisms for much longer than a year. After having learned more about evolution, she described herself as "more firm" in her acceptance of evolution now that she had "evidence to back it up".

In her unprompted discussion of the rationale by which she accepts evolution, she mentioned several lines of evidence including "the fossil record," "similarities between organisms that are related to each other" and "DNA evidence" and gave clear descriptions of how these 
lines of evidence support her acceptance of evolution. When asked which type of evidence she found to be most compelling, she responded, "They're all about equal. They all fit together. The fact that all of the different kinds of evidence agree, that they all support evolution, that's the most compelling thing to me."

However, Becky mentioned that there is one "thing about evolution" that still "gives me some trouble." When discussing human evolution, Becky described it as difficult to accept although she thinks evolution should apply to all species equally:

I think species can evolve into other kinds of species over time, and I know it's a double standard, I mean, if one organism can evolve then why can't another, but when it comes to humans evolving from something else, I'm not sure what to believe. But I'm still thinking about it.

Tim is becoming more accepting of evolution . . to some extent. Tim described himself as "becoming more accepting" of evolution. He said, "I've been opening my mind to the possibility of evolution on some level ..." largely because he "was able to talk to people and read the Bible with them." He continued, "I'm beginning to see that religion and evolution can work together."

Tim claimed that he had come to accept "micro-evolution" because "the fossil record shows that evolution has happened," but only within the same "kind" of organism. He related this to his experience working with animals in a pet store, especially amphibians, saying, "I can see more aquatic salamanders as being possible predecessors to more land-dwelling types, but they're still amphibians." He appealed to his understanding of the fossil record, but he did not find other types of evidence to be compelling, explaining that "similarities in body structures or cells, or even DNA, could just be evidence that they were created by the same designer."

But Tim reported that he was still studying the matter. He intended to enroll in a biology course during his first term at college, and he was interested in learning more about "how scientists say that new species are formed". This appeared to be the leading edge of his "growing acceptance of evolution". In his words:

I don't know if one species can evolve into another species. I know scientists say yes, and I want to say yes, but that clashes sometimes with my religion. So, I have trouble at that point, and also with them saying that man evolved from apes.

Rachel still rejects much of evolutionary theory. Rachel says she used to reject "everything about evolution". "But," she said, "I've learned a lot about evolution in the past year or so, but I'm still not sure if I believe it all." Although she "didn't believe" in evolution prior to taking the course on the subject at AGS, she said:

I thought it was interesting because it was a different view than my own. And because of AGS, when we studied evolution in my high school the next year, I went into it with an open mind.

Rachel explained that she has come to accept some things about evolution, such as, "Polar bears and grizzly bears and black bears might have come from one kind of bear." But she did not think that "one kind of organism can evolve into a completely different kind of thing," and she was quick to add, "and I don't think humans came from monkeys."

Rachel had also reconsidered the way she thought about the age of Earth. She reported that she "used to think the Earth was only six thousand years old," but had begun to think that "Earth might be millions of years old, but not billions." When asked why "not billions", she framed her reasoning in terms of both her understanding of physical evidence and her religious faith:

Well, the fossils do show that animals have been around a long time, so thousands sounds like not long enough. So, maybe millions, but my background is as a Christian, so it can't be too old.

\section{Perceived changes in acceptance of evolution among students who have completed one year of post-secondary study: Cindy, Angela, and Robert}

Cindy accepts evolution even more. Cindy wanted to make clear before discussing her level of acceptance of evolution that she is a Christian, but she went on to say, "I have always tried to keep science and religion separate." Cindy was thenceforth quite eager to discuss her acceptance of evolution, beginning:

I have to admit, my family pretty much accepts evolution, but I think I've always just thought that creationism doesn't make much sense. At least, it doesn't make as much sense as gradual change over time.

Cindy reported that she did not learn very much about evolution in the "very small" high school she attended, explaining, "The biology teacher just said, 'Some people believe in evolution. If you want to know more about it, it's in the textbook. We won't discuss it in class." However, she went on to defend the quality of science education at her alma mater with regard to "non-evolution topics". She 
described a science curriculum which "really stressed experimentation and scientific exploration". Apparently, such experiences played a large role in her understanding of the nature of science and her attitude toward evolutionary science:

My school was really big on science fairs, and even though it's a small school, we compete at the national level in big science fair competitions. That taught me a lot about how science works, and I've seen how much work goes into being able to make and support a scientific claim. To get professional scientists to agree with any idea takes a great deal of work and evidence, so that's why I usually trust science. That goes for evolution too.

Although Cindy is not a science major, she enrolled in two science courses (biology and astronomy) during her first year in her small, public university, and she said "I learned even more about evolution than I knew after AGS." She listed several types of evidence that she claimed to have influenced her "stronger acceptance" of evolution including "fossils," and "observations of small scale changes in things that are around today" which, she explained, "could lead to really big changes over billions of years." Cindy also presented a concise, but clear, explanation of the "Big Bang" theory and of methods used to calculate the age of the universe and the age of Earth.

However, Cindy said, "Human evolution is less clear. We didn't come from monkeys that are around today, but we definitely came from something more primitive." When asked to clarify what she meant by "more primitive", she admitted that she did not "know much about human evolution, but I'm not sure what exactly would have come before what we would call human. I just don't know enough to say."

Angela is becoming more accepting of evolution. "The first time I heard about evolution, I thought it was weird and I didn't really see myself coming from a monkey," said Angela, who described the community in which she was raised as "small and conservative. We all went to the same church, basically." Angela was "raised not to believe in evolution and things the church disagreed with. I always thought I had to hate everything the church hated." However, she explained that "a lot of my views have changed since I went into a new community. When I went to college, I learned I can think for myself." Speaking specifically about evolution, Angela said:

It was uncomfortable at first, but now I think it's cool that God could make a timeline that scientists could follow. I thought it wasn't right that the church fought it so hard because science just has more proof that evolution happened.
Angela reported that she "can agree with scientific evidence like the fossil record," and she said, "we can see animals and things changing now." After explaining that she did not know as much about fossils as she would like to know, she added "I don't think that scientists would forge fossils, and there's really a lot of proof there." Angela concluded the interview after a moment of reflection, saying:

I guess I've come a long way since back in Governor's School. The evidence I've heard supports evolution, and I accept most of it. For people though, I think our bodies keep up with the times, and that's evolution, but I still don't think we came from monkeys.

Robert still rejects evolution, for the most part. Robert was home-schooled until he entered the public school system at the high school level. He describes his reasons for rejecting evolution saying, "I believe in creationism because that's what I was raised to believe," adding, "My mom is a biology teacher, and she's heard a lot about why evolution is probably wrong."

However, Robert explains that "some parts of evolution are real though. Animals adapt, but I don't believe in species evolution." When asked about what types of evidence informed his rejection of evolution, he said he did not know of any scientific evidence "off the top of my head, but I don't really know of any evidence for evolution either." Asked what kind of evidence it would take to convince him that evolution had occurred, he said, "I'd need actual data, maybe even photographs of a species in its evolution process, which is probably impossible since it's supposed to take thousands of years."

Robert had taken a course on astronomy during his first year at a large, public university. He reported that the course had included "a lot about the 'Big Bang' and evolution of stars and galaxies and planets." Although he once believed that "all of creation was made only a few thousand years ago," he had recently "stretched" his conception of cosmological time, saying "the universe may be a couple million years old," and that "Earth is maybe several hundred thousand years old." Asked upon what evidence he had based his ideas of the age of Earth, he replied:

My Christian beliefs, mostly. We know that humans have been around for a few thousand years, but there's no proof that they've been around for millions of years. So, if I don't believe in human evolution, there's no cause for me to believe that the Earth could be millions of years old. 


\section{Perceived changes in acceptance of evolution among students who have completed two years of post-secondary study: Samantha, bill, and Mitch}

Samantha has accepted evolution since elementary school. Samantha was a biology major at a small, private university. Surprisingly, she attributed her decision to major in biology, at least in part, to the lack of teaching of evolution in her high school. She reported that her "high school biology teacher was a creationist, but that didn't affect my thoughts about evolution because my parents taught me a little bit about it," adding, "but we're Catholic, so evolution's OK with us. I keep science separate from my spiritual life." Returning to her discussion of her high school experience, she explained that not learning about evolution in high school "made me want to know more about evolution, especially after AGS", so she "took biology in college and ended up majoring in it."

When asked if she had always accepted evolution, she said she had "never really rejected evolution," and added that "the evidence would have been enough to convince me anyway." However, recalling memories of her ideas "in elementary school," she said:

I think I believed in Adam and Eve and the creation story when I was little, but when I learned about evolution, it was like when I learned about sex. It was new, I guess, but it still seemed right. It didn't bother me. Actually, I was starting to wonder about how Adam and Eve could have worked with all the incest there would have been.

Bill accepts evolution even more, but he has "stopped being an atheist". Bill claimed to have always accepted evolution, but, he explained, "it was mostly because I was an atheist. What else was I going to believe?" "But," he noted, "I've learned a lot in the past few years about evolution and the 'Big Bang, and everything I've learned about it in college has just kept confirming it." Bill very clearly explained the "Big Bang" theory and its supporting evidence, including "the use of Doppler shift to calculate the age of the universe according to how long it has been expanding." He conveniently listed the evidence he thought was in support of evolutionary theory in order of which were most compelling to him. These were "DNA" (which he considered to be "very obvious"), "changes in bacteria and viruses," "the fossil record," "the presence of vestigial features in living organisms," "evidence from developmental biology," and his understanding of "radiometric evidence that the Earth is several billion years old."

Bill concluded the interview by saying that he thought it was important to note that he was no longer an atheist and that this was a recent development. He said:
I was an atheist for a long time, but I like to base my positions on proof. I realized that I didn't have any proof that there is no God, so I couldn't rule it out. Now I believe in God, but only to the extent that I think he only set up the universe so it could run on its own. Evolution happened within the natural laws, and I don't think God would have to push it along.

Mitch has decided to withhold judgment. Mitch described his changed position on acceptance of evolution by saying:

At one time, I was a very dogmatic creationist. Now, I honestly don't know if evolution is real. I'm withholding judgment until sometime in the future when I can look at all the evidence better and get a clearer idea.

Mitch was a biology major at a large, elite, secular, private university, but he had attended a small, private, religious high school. He reported that the majority of what he had learned about evolution in high school was from "an anti-evolution, creationist perspective," which was also the perspective held by his parents. However, he had taken several courses in the life sciences at his university, and all of them had been "taught from evolutionary perspectives". Reflecting on his high school and university experiences, he said:

I had always looked at the evidence against evolution I'd always been taught, and I just rejected [evolution] as a scientifically invalid idea. I realize now that it's more complicated than I originally thought it was.

Mitch explained, with clarity and detail, what he referred to as "micro-evolution" and concluded:

To argue against micro-evolution is just silly. So, I accept micro-evolution, but I'm not yet sure if that implies macro-evolution. I sort of gather that it does, but I'm remaining undecided until I can look at the data myself. I'm a Christian, and I believe in the Bible. I need to know if Genesis is an allegory, so I'll have to study that. If it is, then it's possible that God used macro-evolution to create life's diversity.

Mitch was also "withholding judgment" on the question of the age of Earth. "How old is the Earth? I don't know. It's at least 20 years old." (He laughed. Mitch was 20 years old.) "When I was a more dogmatic creationist, I really believed the Earth was about six thousand years old. Now I'm not totally certain." When asked why he was no longer certain, Mitch explained that he had begun to question whether or not Genesis had been 
intended to be read literally and that he had become "more open-minded about radiometric dating methods" for determining the ages of rocks, and therefore Earth.

Mitch described his "decision to withhold judgment" as "intentional". "Before I decided to withhold judgment," he said, "I would come up with personal theories to explain away the evolution arguments, but I realized they weren't valid until I actually looked at the data myself." He also discussed what he thought had been the hardest part of tentatively relaxing his staunch creationist position, saying, "It was difficult at first just because I had been arguing against evolution for so long. The possibility that I might be wrong hurt my intellectual pride."

\section{Secondary research questions}

In the following section, I present results from student interviews and from open-ended questions that were included with the follow-up survey administered online to participants just over one year after their AGS experience. These results are arranged by research question.

\section{A) What factors do students perceive as influencing their acceptance or rejection of the occurrence of biological evolution?}

The following results are arranged according to their relevance to specific factors and according to whether the data were gathered through interviews or from open-ended survey questions.

\section{Religious factors}

Open-ended questions from the follow-up survey. Of the 37 participants who responded to the follow-up survey administered just over one year after their AGS experience, 36 individuals answered the following open-ended item: "Please explain the reasons why you accept evolution, why you do not accept evolution, or what makes you unsure."

Seven of the respondents framed their answers to this item in terms of their religious beliefs. The following excerpts are typical of participants' responses involving religion:

I'm just unsure about it and my religion makes a large part of the argument.

Because of my religion, I don't believe that humans evolved from monkeys, but I believe that they have evolved enough to survive in the habitat they live in.

Even though I was exposed to evolution, and a lot of the theories make sense, I am not truly convinced. In addition, my religion has played a factor in my reasoning, and it also makes things a little more confusing because it's hard to decide which one I believe.
Thirteen individuals also responded to this openended question: "If your level of acceptance of evolution has changed, what factors (reasons) do you think influenced the change?" Of these respondents, three individuals made reference to religion. Two of these students had become more accepting of evolution. One reported looking for "a way to reconcile my old religious views and my acceptance (NOT blind faith) of evolution" and another reported believing that "God let everything evolve". The third individual who mentioned religion as a factor influencing a change in acceptance of evolution reported that the writings of several creationist authors had led him or her to a position of decreased acceptance of evolution.

Responses from interviews. Twenty out of the 27 participants interviewed framed a portion of their discussion about their acceptance or rejection of evolution around their religious views.

For some, acceptance of evolution was reported to arise, at least in part, due to lack of a religious background. Responses typical of this position were:

My family isn't religious, so, there was never a time when I was shocked by evolution. I just figured the evidence was there even before learning about it.

I'm not religious, maybe God ultimately put us here, but I don't need to believe we didn't evolve.

And recall Bill's quip, "I was an atheist. What else was I going to believe?" For others, rejection of evolution largely, if not entirely, stemmed from resistance rooted in religion. Representative comments of this nature included:

They taught me in church that my faith would be challenged by evolution, but not to give in to the beliefs of the world.

Scientists don't have the answers for everything. Some things they can't prove, but I know God has the answer for this. I'm open to listening, but I will never change my beliefs.

Students also frequently described how their religious faith was not threatened by their acceptance of evolution, and many of these participants felt that evolution and their religion could be "intertwined". Responses like these were quite common:

Why can't God create through evolution?

I'm a Christian, but I think that evolution was a good way for God to create everything. 
I think you can intertwine creation and evolution. I think that evolution is a continuous process, and I still believe in God.

A few students explained their increasing acceptance of evolution by pointing out that they had found flaws with their previous religious beliefs about evolution, including this student's comment about "Intelligent Design":

The most compelling argument for me is how many things that are supposed to be "intelligently designed" still have flaws. They could be more perfect, so why aren't they?

And several students reported that they were wrestling, some with great difficulty, with reconciling the evidence for evolution with their religious faith. These students often made comments like the following:

I haven't always been open to giving evolution a chance. I want to believe it, but I want to believe in my religion too. They will always be in conflict, and I just can't see a way to make them fit. Sometimes I feel like I can accept part of evolution, but I still can't accept all of it.

I see the evidence, and I'm trying to figure out, could [evolution] be real? It's kind of conflicting with my beliefs, and it's kind of confusing.

I didn't believe in evolution before AGS, but now I'm struggling because the scientific evidence I'm learning about points toward evolution. And that's confusing because of my faith.

\section{Non-religious factors}

Evidence Open-ended questions from the follow-up survey. Of the 37 participants who responded to the follow-up survey administered just over one year after their AGS experience, 36 individuals answered the following open-ended item: "Please explain the reasons why you accept evolution, why you do not accept evolution, or what makes you unsure." The most often cited reasons offered in response to this item were those related to evidence. Twenty-five participants (about $70 \%$ of respondents) framed their reasons for accepting evolution around evidence (specific types of evidence mentioned were "the fossil record," "genetic evidence," "embryology" and so on), and three participants mentioned "evidence against evolution" or "lack of evidence for" evolution among their reasons for rejecting evolution.

Additionally, with regard to changes in students' levels of acceptance of evolution, 13 individuals responded to this open-ended question: "If your level of acceptance of evolution has changed, what factors (reasons) do you think influenced the change?" Seven of these participants reported that "evidence" or "further study of evidence" was influential in increasing their level of acceptance of evolution, and another participant cited "lack of evidence" as a reason he or she had become less accepting of evolution.

Responses from interviews. Interview participants were all asked what evidence might have led them to their position of acceptance or rejection of evolution.

Participants who accepted evolution tended to list specific lines of evidence they found to support evolution. The most frequently cited line of evidence was "the fossil record" with the fossil remains of various ancestors of horses and whales being commonly offered as examples, followed in order of frequency of report by "genetics" or "DNA evidence," "vestigial features" or "vestigial structures," "comparative anatomy," "comparative embryology" or "developmental similarities," "biogeography" and "observation of changes" in extant organisms, especially "viruses and bacteria".

Participants who were becoming more accepting of evolution often cited a specific example of evidence which "got my attention" or "really made me have to stop and think". Among these were "fossils that showed real transitional change, like the whales or Archaeopteryx," "things like the lobefin fish that show things that are in between," "how the differences in the cytochrome-c protein were greater for things that were less related," and "when we looked at the different kinds of eyes that showed how something like our eyes could have evolved."

Participants who did not accept evolution tended to be less familiar with evolutionary evidence, although most did find at least some form of evidence of evolution to be at least somewhat "compelling" or "difficult to reconcile". Evolution rejecters sometimes cited lack of evidence or "proof" of evolution or mentioned that they thought there was "too much evidence against evolution". Others doubted the fossil record:

I don't believe that fossils have anything to do with evolution. It just means that whatever that's a fossil of existed previously. It doesn't mean it turned into something else.

And some questioned the honesty of paleontologists in general:

I think sometimes about fossils, what if scientists are just adding a bone here or there, and that makes it look like evolution?

The most resolute evolution deniers also made comments indicating that they may be unable or unwilling to objectively evaluate the evidence; 
No evidence could ever convince me of evolution.

I don't think any evidence could ever change my beliefs about evolution.

Mechanisms Open-ended questions from the follow-up survey. In response to an open-ended question on the follow-up survey, 3 out of 36 respondents claimed that their understanding of one or more evolutionary mechanisms influenced their acceptance of evolution. Natural selection was mentioned by all of these participants, and genetic drift was discussed by one.

Responses from interviews. During the interviews, several participants made statements indicating that "learning how evolution works" was an important factor leading to their assessment of the validity of evolution. All participants were asked to explain their ideas about the mechanisms of evolution, and those who accepted evolution were generally more likely to provide more detailed descriptions of evolutionary mechanisms. However, participants who rejected "macro-evolution" but accepted "micro-evolution" often gave very clear and accurate descriptions of the mechanisms through which evolutionary change occurs.

Nature of science Open-ended questions from the follow-up survey. In response to an open-ended question on the follow-up survey about reasons they accept or reject evolution, 6 out of 36 respondents framed some portion of their responses around ideas related to the nature of science. Three of these students referenced the explanatory power of evolutionary theory as reasons for accepting it as "scientifically valid". Three others provisionally accepted evolution because they viewed it as the only "scientifically testable theory" currently available.

Responses from interviews. Only 7 out of the 27 interviewees discussed their acceptance or rejection of evolution in relation to aspects of the nature of science. Cindy, one of the university students interviewed, cited her understanding of the scrutiny to which claims are subjected in the scientific community as a reason she accepts the consensus of scientists on the matter of evolution. Most others broaching this line of discussion merely described evolution as "the best scientific explanation" even if they personally held views which they realized were "based on faith" and "not scientifically testable". Three interviewees addressed the limitation of science to matters of the "physical" or "natural world," and two of them stressed the importance of keeping "religious" or "spiritual" ideas "separate from" science. One participant added, "Evolution is a matter of science, not an alternative to religion."

Critical thinking and cognitive disposition Openended questions from the follow-up survey. In response to open-ended questions on the follow-up survey about reasons they accept or reject evolution, 8 out of 36 respondents framed some portion of their responses around ideas related to critical thinking. Most of these participants found evolution to be acceptable after "thinking about it logically" and critically comparing evolution to other explanations, concluding that evolution "makes more sense". Additionally, two students reported having become more accepting of evolution as a result of becoming "more open-minded".

Responses from interviews. A substantially larger proportion of the interviewees discussed their cognitive dispositions. Ten of these participants identified having "become more open-minded" as an important factor in their position on acceptance of evolution. This exchange is representative of such responses:

Participant: "Before, I didn't want to learn about evolution, and I'd just get upset. I just felt inside that when somebody said something about evolution, well, I'd just have to defend my views. But now I've learned to be more open-minded, and I'm thinking that maybe the Earth is older than I thought and maybe things can change."

Interviewer: "What helped you become more openminded?"

Participant: "Just seeing how many other people have different views, because where I'm from, pretty much everyone has the same view."

However, one participant's conception of what it meant to be "open-minded" was somewhat less encouraging:

I'm open to listening, but I will never change my beliefs. I won't just walk out of the class if you start talking about evolution, and that's what I mean by being open-minded.

Social and emotional factors Open-ended questions from the follow-up survey. In response to open-ended questions on the follow-up survey about reasons they accept or reject evolution, 7 out of 36 respondents discussed the influence of people with whom they had social relationships. Five of these appealed to the authority of teachers or scientists, and two others mentioned the importance of their parents' beliefs.

Responses from interviews. Over two-thirds of the interviewees discussed the impact their parents' positions on evolution had in shaping whether they accepted or rejected evolution. This trend held true for both acceptors and rejecters. Several participants perceived entire communities (towns, schools, "where I'm from") as being 
rather homogenous with regard to rejection of evolution and described societal pressure to conform to such views. The following excerpts are representative of such comments:

In my town, it's really small, and so, we all believe basically the same way. If you believe differently, it's like, you're kind of weird. So, I've always just accepted what people told me.

I come from one of those places where it's really conservative, and you just don't talk about evolution. No one would ever talk about it, so I thought it was one of those things you just weren't supposed to believe.

Other students described interactions among their peers in school and church. One participant explained:

We got a new youth leader at church who was very anti-evolution. I started to change to not believing in evolution to make everybody happy. But when we learned about it in school, I wanted to see if I really thought it was real, so I had to avoid ever talking about evolution with my friends because they were all creationists. I kept it to myself because I was afraid of what they would think, and I felt really guilty. I didn't want to be ridiculed either.

Feelings of guilt were commonly expressed by students who were beginning to become more accepting of evolution. According to one student, "I understand now that there is a massive amount of evidence supporting evolution. The guilt comes in when I begin to accept it".

Other emotions students expressed in association with their "struggle" with evolution were "frustration," "discomfort" and, of course, Mitch's damaged sense of "intellectual pride". "Discomfort" or "feeling uncomfortable" or "struggling" was also reported by students who claimed no particular religious objection to evolution and, indeed, accepted evolution, with one important exception. Students often expressed these emotions in response to the idea that humans have evolved from non-human ancestors, usually framed in terms of "man from monkeys". Fully half of the students who reported that they "accept evolution" stopped short of acceptance of human evolution. Although most of them cited religious beliefs as the reason for this exception, several appealed entirely to emotional discomfort with the notion of sharing a common ancestor with "monkeys," "apes" or "chimpanzees".

Emotional disturbance was also voiced by participants who accepted evolution and by those who were curious about evolution. Several students who, for various reasons, were eager to learn about evolution expressed "frustration," "anger" and "feeling cheated" by what they perceived to be a hindrance, if not a total obstruction, to opportunities to learning about evolution in their schools and communities. A substantial proportion of participants reported that their high school science teachers had avoided, "watered down," or completely omitted evolution, and fully one-third of the interviewees described their high school biology teachers as "creationist". Even some teachers who reportedly taught about evolution were alleged to have told their students that "it's wrong," or "I don't believe it".

\section{B) How do students perceive these factors to rank in order of influence on their acceptance or rejection of the occurrence of biological evolution? Open-ended questions from the follow-up survey}

Of the 37 students who participated in the follow-up survey, 29 responded to the following question: "Of the reasons you gave for acceptance/rejection of evolution, please rank them in the order of importance (from most important to least important) they have on your level of acceptance or rejection of evolution." By far the most common and highly ranked responses to this item were related to evidence of evolution with ten participants listing evidence as the most important reason that they accept evolution, five listing evidence as the second most important factor, and two others quoting evidence as the third most important factor supporting their acceptance of evolution. However, two more participants reported that they rejected evolution due to what they perceived to be a lack of evidence.

Understanding of the mechanisms of evolution was the next most often listed and highly ranked factor. Religious factors and appeals to the authority of scientists followed next, each being listed by four students as having the most influence on their acceptance levels. Interestingly, half of those who listed religion as the most important factor gave it as a reason that they accept, rather than reject, evolution, one participant saying:

I'm a Christian, and I believe that the Bible actually does back up most of the evolution theory. ... I think if people delved a little deeper in to Genesis 1, I think they would find a lot of similarities between it and evolution theory. This is very important in my acceptance of evolution.

Although several participants simply listed "evidence" as an important and high-ranking factor influencing their acceptance of evolution, many made specific reference to particular lines of evidence. The most commonly listed and highly ranked line of evidence was "the fossil record," followed by evidence related to comparative embryology, with evidence from genetics or biochemistry and direct 
observation of changes in modern populations of organisms being equally frequently reported and highly ranked.

In terms of factors students perceived to have had an influence toward changing their level of acceptance of evolution, nine participants responded to the following open-ended item on the follow-up survey: "Of the factors you listed as influencing any change in your level of acceptance of evolution, please rank them in the order of importance (from most important to least important) they have had in causing any change in acceptance of evolution." The most often cited and highly ranked factor listed by these participants was "further study" of the evidence and mechanisms of evolution. Social factors involving the importance of the ideas and views of friends and family were the next most commonly reported response to this item. Other responses included "being more open minded" and, in the case of the one participant who reported having become less accepting of evolution, "reading The Case for a Creator," a book of creationist apology by Lee Strobel (2004).

\section{Responses from interviews}

Though few interviewees who accepted evolution listed religious or social factors among their ranked catalogues of reasons for accepting evolution, most of them did reference the compatibility of their religious beliefs and their parents' positions on evolution as having had an influence on their acceptance levels. When ranking their reasons for accepting evolution, the majority listed factors related to evidence for evolution, with the "fossil record" being the most frequently cited and highly ranked line of evidence reported, followed by (in order of rank and frequency of report); "DNA" or "genetic evidence," "comparative anatomy," "vestigial features," "observing" or "seeing" changes in "organisms living today," "evidence from embryology," and "biogeography".

Interviewees who reported having become more accepting of evolution offered a similar list of ranked evidence, but were more likely to list having become "more openminded" as the primary reason that they were less resistant to evolutionary ideas, and most of these attributed the change in their cognitive disposition to "seeing" or "realizing" that "evolution and religion" or "evolution and faith" or "evolution and Christianity" were not incompatible. Others cited "listening to" or "considering" other people's "views" or "ideas" as having contributed to the opening of their minds regarding evolution.

Interviewees who rejected evolution also sometimes referred to evidence as a factor influencing their acceptance of evolution; however, this was usually to say that there was a "lack of evidence" or "holes in the evidence" or "not enough proof". Participants who rejected evolution were more likely to list "the Bible" or "religious beliefs" as the chief factor affecting their position regarding evolution, and the second most frequently and highly ranked factor cited by evolution rejecters was that they had been "taught" or "raised" not to believe in evolution.

\section{C) What patterns arise among students' articulations of why their level of acceptance or rejection of the occurrence of biological evolution has changed?}

Perhaps the most striking pattern emerging from the analyses of these data is that the landscape of factors students report as influencing their changing levels of acceptance of evolution is complex and individualized. Each student represents a different blend of prior knowledge, family background, religious belief, community history, level of interest and cognitive disposition, and their reasons for accepting or rejecting evolution can differ greatly between individuals. Also, many factors appear to be intertwined. However, there are trends among the participants' reports.

It appears that students who accept evolution appeal more strongly to evidence than those who are unsure about or reject evolution.

Students appeal to their religion as a factor influencing their level of acceptance of evolution whether they accept evolution, reject evolution or are becoming more accepting of evolution.

Another trend that appears to emerge across positions on acceptance of evolution is the difficulty students have with the evolution of humans from non-human ancestors. Over half of the interview participants expressed such difficulty, even those who "fully accept" evolution as "scientifically factual" and "definitely true," and whether the "difficulty" is rooted in religion or merely in emotional "discomfort". One participant offered insight into an aspect of the course that had allowed her to consider human evolution as "possible". She explained, "When we learned that humans didn't come from chimpanzees or monkeys that we have today, but that we had common ancestors with them, that really helped."

Students who reported having become more accepting of evolution tended to report their positions in terms of what "God," in their understanding, "could have done". For example:

God could have created everything using evolution as a tool.

God could have created environmental conditions for things to change, so evolution could happen.

God could have created the first cells and kind of just let it go from there.

Other trends among students who reported an increase in their level of acceptance of evolution included 
"stages" of changed acceptance. Generally, the first concessions involved the age of Earth and/or of the universe. The majority of students who reported having initially believed in Young-Earth creationism later reported "progressing" to "Day-Age" creationism, under which they interpreted the six days of the Genesis creation story to represent vast periods of time rather than six literal days, or to accepting an increasingly long natural history. About half of the self-professed creationists interviewed claimed to have entered the course already accepting "micro-evolution," and several more came to accept "small-scale changes" or "adaptation". Many of these participants reported that they had expanded what they could accept about "species evolution" and "macroevolution".

\section{Additional findings}

\section{Lack of teaching of evolution in high schools}

Another trend emerged from the analysis of the interview data regarding participants' prior experiences with evolution education. While 7 out of the 27 participants reported that evolution had been covered "very well" or "very thoroughly," in their education to date, almost two-thirds of the interviewees reported that evolution was not taught "properly" or "effectively" - in some cases, not "at all". Many of them reported that their teachers "didn't discuss" evolution or that they "didn't mention the 'e-word," often, the students suspected, because they "didn't want to offend anyone". One participant reported that her "biology teacher talked about it for a while," but that "we weren't tested over it. It made a lot of people not care because they wouldn't be tested, so they didn't listen."

An alarming proportion of participants reported that their high school biology teachers said that they "didn't believe in evolution" or made comments about evolution such as, "it's not my view, but you have to learn it"; another participant offered that his biology teacher regarded evolution as "just plain crazy". Describing the treatment of evolution in her high school biology class, one participant said, "My teacher covered evolution in less than seven minutes. She said she didn't believe it and we didn't have to either."

Additionally, even participants who reported that their science teachers did teach evolution told the interviewer that their teachers "affirmed" their "Christianity" or "faith in God," sometimes "repeatedly," in the context of teaching evolution.

These reports were consistent with students' responses to an open-ended question that appeared on an informal, pre-course survey that had been administered to students in the evolution course as well as three previous iterations of the course on evolution at AGS. The question read, "How well is evolution covered in your high school classes?" While about one-third of the students reported that they thought evolution had been covered "pretty well," or "very well," that they "spent" a number of "weeks" or "days" on evolution, or that they "had a whole unit on the topic," it was more common for students to respond with answers like, "not at all," "barely touched on it," or, with a bit of pre-college humor, "diddly squat".

\section{Concerns of students at the beginning of the course}

Another item on the pre-course survey invited students to express any concerns they might have about the course about which the instructor ought to know. By far, the majority of the students responded that they had no particular concerns, although students did report sundry concerns every year. Among these were comments like:

I'm a very religious and devout Christian, and I believe in Creation.

I would like to know the whole story about evolution, and not just a biased account.

I'm concerned that evolution might be forced on me as a belief.

I hope that all the holes in evolutionary theory are also presented.

And one student offered that he was "concerned that I might get in trouble for proving that evolution is false!"

\section{Enjoyment and appreciation}

Other items on the formal course evaluation asked students about how interesting they found the course to be and how the class had contributed to their AGS experience. Responses to these items were overwhelmingly positive. For example:

I never had the slightest interest in evolution until now. I found it VERY interesting. It was a class I looked forward to.

The material was intriguing and well-covered. Evolution is so cool now! It broadened my views on our world and how it came to be. I looked forward to this class every day.

I didn't know much about evolution because I'm Christian and just rejected it. But now I embrace it. This class really changed my perspective not only on evolution, but on life. I now have a totally different view on life. I'm going to miss this class. 
Furthermore, the final item on the course evaluation asked, "Do you have any other comments about this class and/or instructor?" One of the most frequent types of response to this question involved students thanking the instructor for having taught the course, many of them saying that they appreciated the opportunity to learn about evolution because it is not taught in their high schools.

\section{Is it important to learn about evolution?}

All interviewees were asked whether or not they thought it was important to learn about evolution. All of these participants, even those who resolutely rejected evolution, reported that they thought it was important to learn about evolutionary science.

\section{Conclusions}

Combined, the results of Wiles and Alters (2011) and the qualitative data reported herein have measured and examined changes in students' evolution acceptance levels after an educational experience incorporating an inventory of factors identified as potentially influencing students' acceptance of evolution (Wiles and Alters 2011). Furthermore, students' perceptions of their acceptance of evolution and any changes therein were explored, and insight was sought regarding the factors which participants perceived to have influenced their acceptance of evolution. Wiles and Alters (2011) presented a thorough review of the prior literature on factors thought to potentially influence student acceptance of evolution (these factors are also listed in Carter \& Wiles (2014)), and each factor identified was mentioned by at least some of the participants as having influenced their position.

Students who accepted evolution prior to the AGS course on evolution leaned heavily on evidence as the most influential factors, but many of them also cited their parents' or other social acquaintances' acceptance of evolution or the compatibility of their religious views with evolution as supporting factors influencing their acceptance of evolution.

Students who had become more accepting of evolution often discussed having become "more open-minded" about their religious interpretations or about evolution in general before they mentioned scientific factors like evolutionary evidence, and some of these participants attributed their increased receptiveness to new ideas to having been introduced to people whose views differed from their own. Perhaps this marks a decrease in their previous levels of the "Feeling of Certainty" (Ha et al. 2012) in their prior rejection of evolution. A few students listed factors related to critical or "logical" thinking or to the nature of science, the limitations of science, or "how science works". These data suggest that religious factors, social factors and emotional factors, as well as students' attitudes toward science and their understanding of the nature of science, are likely to be key factors involved in accessing the deferral of judgment regarding acceptance of evolution for which Pigliucci (2002, 2007) suggested science educators should seek. Factors related to critical thinking skills, epistemological views and cognitive dispositions are apparently similarly important, and perhaps, therefore, ought to be addressed prior to, and in preparation for, exposure to material on the scientific factors involving the evidence for and the mechanisms of evolution.

Students who continued to reject evolution largely reported that their positions were based on religious beliefs, which, aside perhaps from those that are directly tied to scientific misconceptions, lie outside of science teachers' sphere of responsibility. However, even these students, given time, may eventually, and gradually, accept more aspects of evolutionary science, as in the case of Mitch, who has "decided" to "withhold judgment" pending further study. And indeed, it can take a great deal of further study to effect large-scale change in a creationist student's level of acceptance of evolution, as described by Godfrey and Smith (2005).

Creationists who do transition to higher levels of acceptance of evolution apparently do so, at least in several instances described herein, through a series of concessions which are common across cases. These concessions include acceptance of older ages for Earth and/ or the universe (whether through perceived "gaps" in religious accounts or through "Day-Age" interpretations), acceptance of "micro-evolution" and associated expansion of what that can include, and more flexible religious notions of what "God could have" done. These stages appear to coincide with various points along Scott's (2004) creation/evolution continuum. The evolution of humans from non-human ancestors is apparently the most difficult aspect of evolutionary science for many students to accept, and it is often the final point of rejection among students who otherwise accept evolutionary science.

Finally, with regard to the widespread public rejection of evolution, it is reasonable to speculate that much of the general population's misunderstanding of and subsequent resistance to evolution may well be due to how evolution is treated, or rather, is not treated, in public school science classes. Although many of the participants in this study reported satisfactory treatment of evolution in their schools, the frequency of reports from participants alleging downplaying, omission or even denigration of evolution by their science teachers is deplorable. But such practices are apparently not uncommon. These student accounts are consistent with previous reports about evolution education in Arkansas (Wiles 2006a), other states (Moore and Kraemer 2005; Weld 
and McNew 1999), and across North America (National Science Teachers 2005; Wiles 2006b, 2006c; Wiles and Branch 2008; Berkman and Plutzer 2011).

Additionally, there is a complex and individualized landscape of factors that students perceive to influence their acceptance of evolution. This likely reflects the varying blend of scientific concepts and naïve cognitive biases they draw upon in forming their understandings and positions, as Opfer et al. (2012) described. Although most of them referenced the compatibility of their religious beliefs and their parents' positions on evolution as having had an influence, the majority of participants who accepted evolution ranked factors related to evidence most highly among those leading to their acceptance. The fossil record was the most frequently cited and highly ranked line of evidence reported, followed by evidence from genetics, comparative anatomy, observation of recent changes, developmental biology and biogeography. Participants who had become more accepting of evolution offered a similar list of ranked evidence, but were more likely to list having become "more open-minded" as the primary influencing factor. This change in cognitive disposition was largely attributed to perceived compatibility between science and religion or to social factors involving exposure to people with diverse ideas. Participants who rejected evolution were more likely to list "the Bible" or "religious beliefs" as the chief factor affecting their position regarding evolution, and the second most frequently and highly ranked factor cited by evolution rejecters was that they had been "taught" or "raised" not to believe in evolution, which is consistent with the findings of Woods and Scharmann (2001) that social factors were second only to religious factors toward rejection of evolution. When discussing evidence, these students were more likely to refer to their perceptions of its insufficiencies rather than having any value toward convincing them of the veracity of evolution.

Patterns and trends common among groups of participants emerged from the qualitative data. Among these trends it appears that students who accept evolution appeal more strongly to evidence than those who are unsure about or reject evolution; that students often appeal to their religion as a factor influencing their level of acceptance of evolution whether they accept evolution, reject evolution or are in transition; that students may have difficulty with the evolution of human beings even if they accept all other aspects of evolution; and that students often come to terms with evolution by revising what they believe "God could have done". Other trends suggest that students who become more accepting of evolution may go through "stages" of changed acceptance involving acceptance of increasingly ancient ages for Earth and universe and expanding limits within which they accept that evolution can occur.
Within the scope of the investigations described herein and more quantitatively illuminated in Wiles and Alters (2011), it can be said that there were substantial changes in some participants' evolution acceptance levels following a focused academic experience designed to incorporate an inventory of factors which were suspected to influence student acceptance of evolution. Furthermore, student reports confirmed that the suspected factors addressed by the course did indeed influence their acceptance of evolution. Should these results be further confirmed through future investigations, the implications are at once encouraging and potentially far-reaching. Further exploration of the relative influence various factors may have on student acceptance of evolution should be explored by means of standardized instruments administered to a much larger sample across student populations in varying geographic locations, institution types, academic majors and academic levels. This is line with the conclusion of Lloyd-Strovas and Bernal (2012) that future studies in the field of evolution education ought to "build upon each other and allow us to move beyond detecting patterns of association among constructs to investigating the causality of those relationships" (p. 464). Investigating these causalities is at the very heart of this study and future efforts which it will inform.

Finally, insight should be sought through further dialogue with students who are resistant to evolution and students who have been identified as potentially becoming more accepting of evolution. Conversations with such students may give teachers at all levels more insight into what methods may work and whether their efforts may impact these students, even if the effects may not be immediately manifest.

\section{Appendix A}

\section{Questionnaire}

1) Do you accept evolution as a scientifically factual phenomenon? (Select one)

\section{No \\ Unsure \\ Yes}

2) Please explain the reasons why you accept evolution, why you do not accept evolution, or what makes you unsure.

3) Of the reasons you gave for acceptance/rejection of evolution, please rank them in the order of importance (from most important to least important) they have on your level of acceptance or rejection of evolution. 
4) Do you think your level of acceptance or rejection of evolution has changed in the last year? (Select one.)

Yes. I have become less accepting of evolution.

No. There has been no change in my level of acceptance or rejection of evolution.

Yes. I have become more accepting of evolution.

5) If your level of acceptance of evolution has changed, what factors (reasons) do you think influenced the change?

6) Of the factors you listed as influencing any change in your level of acceptance of evolution, please rank them in the order of importance (from most important to least important) they have had in causing any change in acceptance of evolution.

\section{Abbreviations}

AGS: Arkansas Governor's School; DNA: Deoxyribonucleic acid

\section{Competing interests}

The author declares that he has no competing interests.

\section{Acknowledgements}

The author would like to thank the staff and students of the Arkansas Governors School for their participation in this research.

\section{Author details}

'Department of Biology, Syracuse University, 107 College Place, Syracuse, NY 13244, USA. ²Department of Science Teaching, Syracuse University, 101 Heroy Lab, Syracuse, NY 13244, USA. ${ }^{3}$ Department of Earth Sciences, Syracuse University, 204 Heroy Lab, Syracuse, NY 13244, USA. ${ }^{4}$ Evolution Education Research Centre, McGill University, Montréal, QC, Canada.

\section{Received: 27 August 2013 Accepted: 9 January 2014}

Published online: 05 April 2014

\section{References}

Alters, B. (1997). Should student belief of evolution be a goal? Reports of the National Center for Science Education, 17(1), 15-16.

Alters, B, \& Nelson, CE. (2002). Teaching evolution in higher education. Evolution: International Journal of Organic Evolution, 56(10), 1891-1901.

American Association for the Advancement of Science (AAAS) (2011). Vision and change in undergraduate biology education: a call to action. http://visionandchange.org/files/2013/11/aaas-VISchange-web1113.pdf. Accessed 1 January 2014

Arkansas House Bill 2548 (2001)

Arkansas House Bill 2607 (2005)

Berkman, MB, \& Plutzer, E. (2011). Defeating creationism in the courtroom, but not in the classroom. Science, 331(6016), 404-405.

Bishop, BA, \& Anderson, CW. (1990). Student conceptions of natural selection and its role in evolution. Journal of Research in Science Teaching, 27(5), 415-427.

Carter, BE, \& Wiles, JR. (2014). Scientific consensus and social controversy: exploring relationships between students' conceptions of the nature of science, biological evolution, and global climate change. Evolution: Education and Outreach. doi:10.1186/s12052-014-0006-3.

Cobern, WW. (1994). Belief, understanding, and the teaching of evolution. Journal of Research in Science Teaching, 31(5), 583-590.

Dobzhansky, T. (1973). Nothing in biology makes sense except in the light of evolution. The American Biology Teacher, 35, 125-129.

Epperson et al. v. Arkansas (1968). 393 U.S. 9789 S. Ct. 266; 21 L, 228. 2nd edn. US LEXIS, 328

Glaser, BG, \& Strauss, AL. (1967). The Discovery of Grounded Theory: Strategies for Qualitative Research. Chicago, IL: Aldine Transaction.
Godfrey, SJ, \& Smith, CR. (2005). Paradigms on Pilgrimage: Creationism, Paleontology, and Biblical Interpretation. Toronto, ON: Clements Publishing.

Gould, SJ. (2001). Foreword. In B Alters \& S Alters (Eds.), Defending Evolution: A Guide To The Creation/Evolution Controversy (pp. 1-4). Sudbury, MA: Jones \& Bartlett.

Gross, P, Goodenough, U, Haack, S, Lerner, LS, Schwartz, M, \& Schwartz, R. (2005). The State Of Science Standards. Washington, DC: Thomas B. Fordham Institute.

Ha, M, Haury, DL, \& Nehm, RH. (2012). Feeling of certainty: uncovering a missing link between knowledge and acceptance of evolution. Journal of Research in Science Teaching, 49(1), 95-121.

Ingram, E, \& Nelson, CE. (2006). Relationship between achievement and students' acceptance of evolution or creation in an upper-level evolution course. Journal of Research in Science Teaching, 43(1), 7-24.

Kearney, PS. (1999). Accepting evolution as an idea. Reports of the National Center for Science Education, 19(1), 13-14

Lawson, AE, \& Worsnop, WA. (1992). Learning about evolution and rejecting a belief in special creation: effects of reflective reasoning skill, prior knowledge, prior belief and religious commitment. Journal of Research in Science Teaching, 29(2), 143-166

Lerner, LS. (2000). Good Science, Bad Science: Teaching Evolution In The States. Washington, DC: The Thomas B. Fordham Foundation.

Lloyd-Strovas, JD, \& Bernal, XE. (2012). A review of undergraduate evolution education in U.S. universities: building a unifying framework. Evolution Education \& Outreach, 5(3), 453-465.

Maxwell, JA. (2005). Qualitative Research Design: An Interactive Approach (2nd ed.). Thousand Oaks, CA: Sage Publications.

McLean v. Arkansas Board of Education (1982). 529 F. Supp. 1255. (ED Ark. 1982) $1258-1264$

Meadows, L, Doster, E, \& Jackson, DF. (2000). Managing the conflict between evolution and religion. The American Biology Teacher, 62(2), 102-107.

Miles, MB, \& Huberman, AM. (1994). Qualitative Data Analysis: An Expanded Sourcebook. Thousand Oaks, CA: Sage Publications.

Moore, R, \& Kraemer, K. (2005). The teaching of evolution \& creationism in Minnesota. The American Biology Teacher, 67(8), 457-466.

National Academy of Sciences. (1998). Teaching About Evolution And The Nature Of Science. Washington, DC: National Academy Press.

National Academy of Sciences. (2008). Science, Evolution, And Creationism. Washington, DC: National Academy Press.

National Center for Science Education (2005). Uncertainty about the Beebe disclaimer. http://ncse.com/news/2005/02/uncertainty-beebe-disclaimer00573. Accessed 25 August 2013.

National Science Teachers Association (2005). Survey indicates science teachers feel pressure to teach nonscientific alternatives to evolution. http://www.nsta.org/publications/surveys/survey20050324.aspx. Accessed 25 August 2013.

Nehm, RH, \& Schonfeld, IS. (2007). Does increasing biology teacher knowledge of evolution and the nature of science lead to greater preference for the teaching of evolution in schools? Journal of Science Teacher Education, 18(5), 699-723

Nelson, CE. (2007). Teaching evolution effectively: a central dilemma and alternative strategies. McGill Journal of Education, 42(2), 265-283.

NGSS Consortium of Lead States. (2013). Next Generation Science Standards: By States, For States. Washington, D.C.: National Academy Press.

Opfer, JE, Nehm, RH, \& Ha, M. (2012). Cognitive foundations for science assessment design: knowing what students know about evolution. Journal of Research in Science Teaching, 49(6), 744-777.

Pigliucci, M. (2002). Denying Evolution: Creationism, Scientism, And The Nature Of Science. Sunderland, MA: Sinauer Associates.

Pigliucci, M. (2007). The evolution-creation wars: why teaching more science just is not enough. McGill Journal of Education, 42(2), 285-306.

Sager, C (Ed.). (2008). Voices For Evolution (3rd ed.). Berkeley, CA: National Center for Science Education.

Scharmann, LC. (1990). Enhancing an understanding of the premises of evolutionary theory: the influence of a diversified instructional strategy. School Science and Mathematics, 90(2), 91-100.

Scott, EC. (2004). Evolution vs. Creationism: An Introduction. Westport, CT: Greenwood Press.

Sickel, AJ, \& Friedrichsen, P. (2013). Examining the evolution education literature with a focus on teachers: major findings, goals for teacher preparation, and directions for future research. Evolution: Education and Outreach, 6, 23. 
Sinatra, GM, Southerland, SA, McConaughy, FM, \& Demastes, JW. (2003). Intentions and beliefs in students' understanding and acceptance of biological evolution. Journal of Research in Science Teaching, 40(5), 510-528.

Smith, MU. (1994). Belief, understanding, and the teaching of evolution. Journal of Research in Science Teaching, 31(5), 591-597.

Smith, MU. (2010a). Current status of research in teaching and learning evolution: I. Philosophical/epistemological issues. Science \& Education, 19(6-8), 523-538.

Smith, MU. (2010b). Current status of research in teaching and learning evolution: II. Pedagogical issues. Science \& Education, 19(6-8), 539-571.

Smith, MU, \& Scharmann, LC. (1999). Defining versus describing the nature of science: a pragmatic analysis for classroom teachers and science educators. Science Education, 83(4), 493-509.

Smith, MU, \& Siegel, H. (2004). Knowing, believing, and understanding: what goals for science education? Science \& Education, 13(6), 553-582.

Southerland, S, \& Sinatra, G. (2003). Learning About Biological Evolution: A Special Case Of Intentional Conceptual Change. In G Sinatra \& PR Pintrich (Eds.), Intentional Conceptual Change (pp. 317-348). Mahwah, NJ: Lawrence Erlbaum Associates.

Southerland, S, Sinatra, G, \& Matthews, M. (2001). Belief, knowledge, and science education. Educational Psychology Review, 13(4), 325-351.

Strauss, A, \& Corbin, J. (1998). Basics Of Qualitative Research: Procedures And Techniques For Developing Grounded Theory. London: Sage Publications.

Strobel, L. (2004). The Case For A Creator. Grand Rapids, MI: Zondervan.

Weld, J, \& McNew, JC. (1999). Attitudes toward evolution. The Science Teacher, 66(9), 26-31.

Wiles, JR. (2006a). Is evolution Arkansas's "hidden curriculum"? Reports of the National Center for Science Education, 25(1-2), 32-36.

Wiles, JR. (2006b). A threat to geoscience education: creationist anti-evolution activity in Canada. Geoscience Canada, 33(3), 135-140.

Wiles, JR. (2006c). Evolution in schools: where's Canada? Education Canada, $46(4), 37-41$.

Wiles, JR (2008). The Huckster's artful dodging on evolution. Inside Higher Ed. http://www.insidehighered.com/views/2008/01/11/wiles. Accessed 25 August 2013.

Wiles, JR. (2010). Overwhelming scientific confidence in evolution and its centrality in science education - and the public disconnect. The Science Education Review, 9(1), 18-27.

Wiles, JR, \& Alters, B. (2011). Effects of an educational experience incorporating an inventory of factors potentially influencing students' acceptance of biological evolution. International Journal of Science Education, 33(18), 2559-2585.

Wiles, JR, \& Branch, G. (2008). Teachers who won't, don't, or can't teach evolution properly: a burning issue. The American Biology Teacher, 70(1), 6-7.

Wilson, DS. (2005). Evolution for everyone: how to increase acceptance of, interest in, and knowledge about evolution. PLoS Biology, 3(12), e364.

Woods, CS, Scharmann, LC (2001). High school students' perceptions of evolutionary theory. Electronic Journal of Science Education, 6(2). http://ejse.southwestern.edu/article/view/7676/5443. Accessed 1 February 2014

doi:10.1186/s12052-014-0004-5

Cite this article as: Wiles: Gifted students' perceptions of their acceptance of evolution, changes in acceptance, and factors involved therein. Evolution: Education and Outreach 2014 7:4.

\section{Submit your manuscript to a SpringerOpen ${ }^{\circ}$ journal and benefit from:}

- Convenient online submission

- Rigorous peer review

- Immediate publication on acceptance

- Open access: articles freely available online

- High visibility within the field

- Retaining the copyright to your article

Submit your next manuscript at $\gg$ springeropen.com 